\title{
Effect of Paper Waste as Cement Replacement in Rammed Earth Construction
}

\author{
Nouman Khan Usama ${ }^{1}$, Khan Shahzada ${ }^{2}$, Muhammad Alam ${ }^{3}$, Sami Ullah Khan Babar ${ }^{4}$ \\ ${ }^{1}$ Department of Civil Engineering, University of Engineering Technology, Peshawar, Pakistan, \\ noumankhanusama@gmail.com \\ ${ }^{2}$ Department of Civil Engineering, University of Engineering Technology, Peshawar, Pakistan, \\ khanshahzada@uetpeshawar.edu.pk \\ ${ }^{4}$ Department of Civil Engineering, University of Engineering Technology, Mardan, \\ emalam82@gmail.com \\ ${ }^{4}$ Department of Civil Engineering, University of Engineering Technology, Peshawar, \\ samiullahkhanbabar@gmail.com
}

\begin{abstract}
The focus on sustainability is at its peak in the construction industries in the last couple of decades. That includes green constructions such as rammed earth construction. Due to media exposure and carbon emission, people are undeniably turning to green and sustainable buildings. Furthermore, there is an improper management pattern of solid waste management found in developing countries, such as open burning and dumping of solid wastes. In which paper waste is not handled in a good way. There are few places in developing countries where developing countries follow proper management of solid waste. Paper waste is present in each city because people are using it for daily life. Paper waste has fibre in them and has cellulose content. These components of paper waste are suitable for compressive strength. It has a side effect that it increases water absorbability. The reason for this research work is to reduce paper waste and reduce cement content. This paper also aims to find the durability and strength properties of rammed earth construction.

Rammed earth construction with paper waste may help to get better compressive strength. But there is a need to check its water absorption and durability properties since these properties are linked.

The soil in this research was sandy silt with clay (Therefore, samples for compressive testing were made, along with models for water absorption and accelerated erosion test, for shrinkage test walls were completed. The results of compressive strength of samples with 2-6\% paper waste were that 2-6\% paper waste rammed earth construction strength results were lesser compare to control samples. But the 8 and $10 \%$ paper waste samples have much more strength compare to the control samples. The $10 \%$ paper waste rammed earth sample have a forte more in comparison with the control sample. The models satisfied water absorption and accelerated erosion test. The shrinkage test showed little difference compared to the control samples.
\end{abstract}

Key words: Rammed earth construction, Water absorption, Paper waste, Shrinkage

\section{INTRODUCTION}

Construction industries are main source of income in any country growth but this also means more cement production [1]. Cement production is not good for environment. In old times rammed earth construction were used as construction. In Roman times, the elder the Pliny, a famous roman author, era approximately $79 \mathrm{AD}$. They were using blood as a stabilizer in those types of buildings. Before this rammed earth construction are used in Europe, China and elsewhere [2], hints are there. The suitability of rammed earth construction depends on the type of soil we are constructing rammed earth constructions. The practicality is that the ideal soil type is challenging to accomplish [3][4]. There are two types of rammed earth construction; this research use stabilized rammed earth construction [5]. Rammed earth construction consists of layers compacted hard with the help of rammer [6]. The moisture content in stabilized cement rammed earth construction is directly related to strength [7]. Researches are carried out to reduce rammed earth construction like fly ash used in rammed earth. Although it helped improve strength, it is unsuitable to use fly ash in developing countries due to the high-cost issue [8]. Rice husk ash was also used in rammed earth construction. It was found that using rice husk ash reduced shrinkage property [9]. Binod Khadha in 2016 used animal dung in rammed earth construction. It has diminished shrinkage in rammed earth construction [10]. There is a contradiction in selecting appropriate water content, like the Newzeland standard (NZ 4298), which states that $4 \%$ moisture content is acceptable [11]. Gypsum is recently used in rammed earth construction, and it counts as a stabilizer but is not suitable for developing countries [12]. Recently polystyrene is embedded in rammed earth construction [13]. Paper has fibrous nature. This fibrous nature is known by doing scanning electron microscopy [14]. 
We also know that paper waste can increase strength due to cellulose presence, but it also increases water absorption [14]. Pakistan generates bundles of wastes annually. In 2018 20 million tons of garbage were generated. Each year the waste gets increased by an increment of $2.4 \%$ [15]. Nearly more than 2.01 billion metric tons of solid waste are made in the world [16]. In 2018 Arooz found the durability of mud concrete blocks by waster absorption test. She was satisfied with the results. She conducted a water spray test [17]. In 2014 Quoc-bao Bui showed that with the increase in moisture content, the strength of the rammed earth sample remains the same [18].

In 2019 Navarro Ferronate explained that in developing countries, the main issue is mismanagement of solid wastes. This mismanagement includes the open burning and dumping of various wastes [19]. Curing for rammed earth construction is good until 28 days. Since if we increase curing days more than 28 , there is no effect of curing on the sample's strength [20]. Sugarcane bagasse ash was used in concrete by cement weight in 2017 by R.vignesh. He used sugar can bagasse ash of 2,4,6,8 and $10 \%$ replaced by cement weight [21]. For rammed earth construction samples, the humidity is essential to consider. The laboratory humidity in where the cylinders are placed should be above $70 \%$, and the temperature should be controlled around 25 degrees [22]. Shrinkage in rammed earth construction is a concern, especially in sandy type soil. Therefore, to find shrinkage, Kariawasam has prepared a setup in research work. He prepared shrinkage setup because he visited 25 building, and some of the building has cracks of more than $5 \mathrm{~mm}$. Therefore, he performed the shrinkage test [23]. He also checks the durability of rammed earth samples by water absorption test and performed accelerated erosion test [23].

\section{METHODOLOGY}

To achieve objectives, it was decided to divide work into six phases. In the first phase, it was decided to collect soil and paper waste sample. Different tests were performed, such as liquid limit, plastic limit and specific gravity in the second phase. In the third phase, control samples were made with different paper waste samples. In the fourth phases curing of samples were done, and compressive strength was calculated. In the fifth phase, six wall samples were made, and shrinkage was calculated. In the last stage, water absorption and accelerated erosion test were performed. The methodology process is shown in Figure 1.

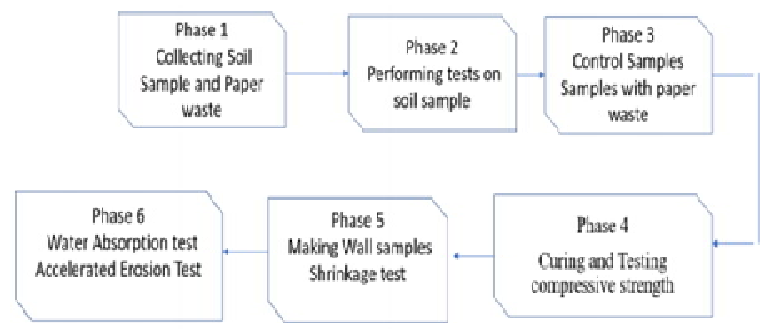

Figure 1: Methodology

\subsection{Collecting Soil Sample and Paper Waste}

In this first phase, soil was collected from Palosai Makdarzai as shown in Figure 2, but the specific gravity was less than 2.0, which means that the soil is organic and deemed unfit for rammed earth construction. The soil was then taken from Umer Jhara District Charsadh. For paper waste, different options were taken into consideration. The paper waste from Qissa Khwani Bazar as shown in Figure 3 and was selected since it was already in the ground state. The paper waste was passed from sieve \# 200.

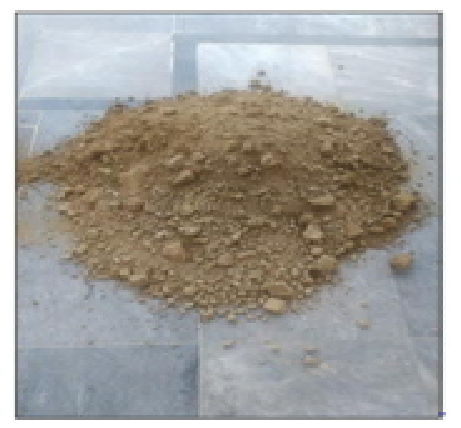

Figure 2: Soil Sample

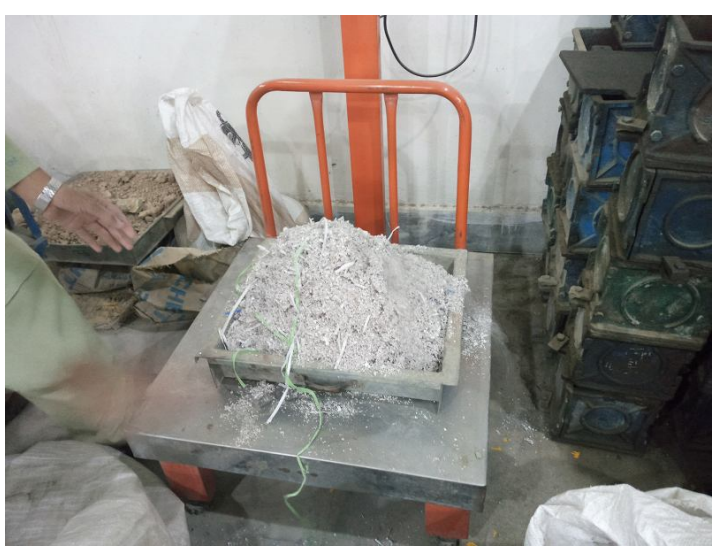

Figure 3: Paper waste sample

\subsection{Performing different tests on soil sample}

As per standard, the soil was made artificially since the standard soil suitable for rammed earth construction was not available for constructing rammed earth sample. Sand and gravel part was collected from the stock and which is $68 \%$ of the soil sample. The clay and silt part were taken from Charsada Umer Jhara. Thus $25 \%$ of particles were less than sieve \# 200. The hydrometer analysis is performed, and the clay percentage was 26.9 in the Umer Jhara Charasda soil sample, which is $25 \%$ of the total soil sample. Thus, the clay particle percentage was 6.725 , and the silt particles were 18.275, as shown in Figure 4. 
Nouman Khan Usama et al., International Journal of Emerging Trends in Engineering Research, 9(7), July 2021, 865 - 869

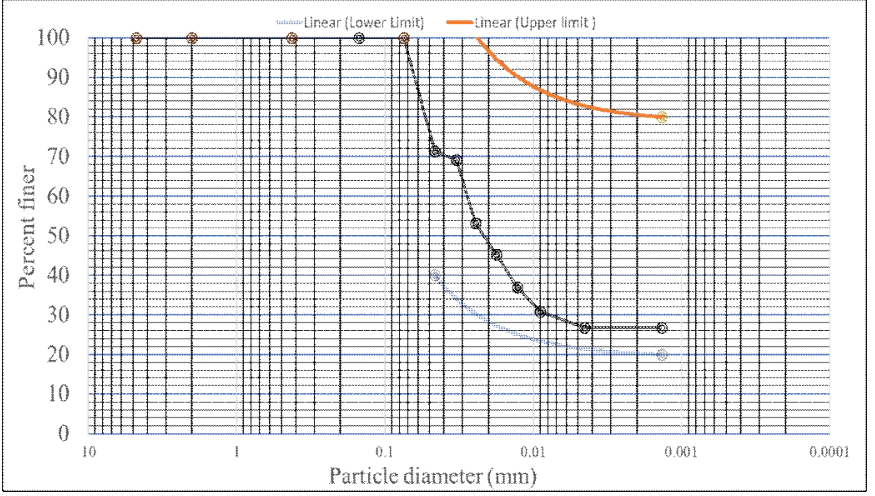

Figure 4: Hydrometer Analysis

Specific gravity was performed on soil sample for classifying and checking the soil nature. The specific gravity was found to be 2.68 then the liquid limit was determined shown in Figure 6, which is $25 \%$. The plastic limit was also found out as shown in Figure 5, which is $21.6 \%$. Thus, the plasticity index was 3.4.

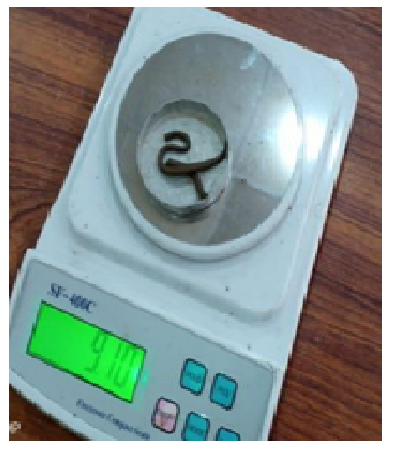

Figure 5: Plastic limit test

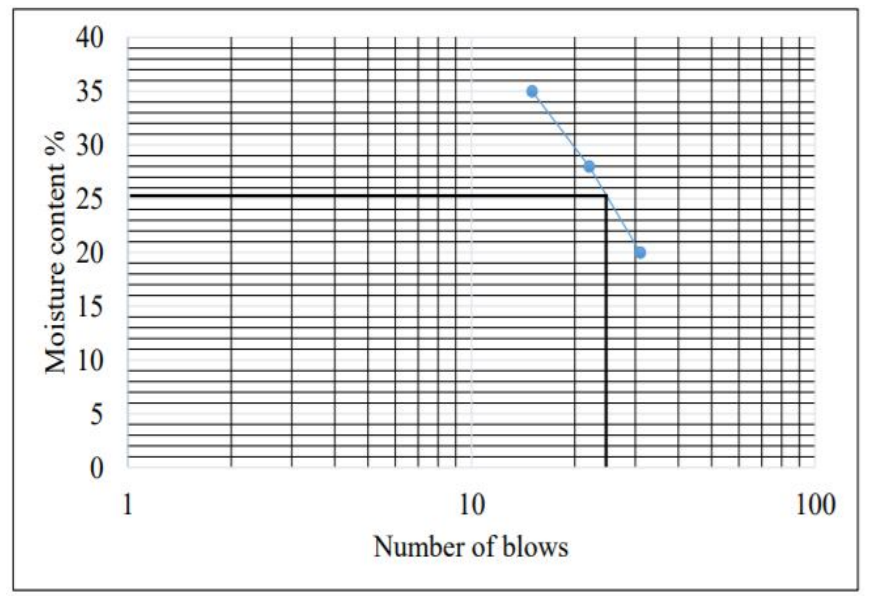

Figure 6: Liquid limit test result

The rammed earth sample was prepared using proper compaction. The cylinder was designed using standard [11]. The sample for compressive strength, water absorption and accelerated erosion test was designed according to the standard as shown in Table 1.
Table 1: Sample composition and number of samples

\begin{tabular}{|c|l|l|c|}
\hline S.No & \multicolumn{1}{|c|}{ Sample Composition } & \multicolumn{1}{c|}{ Number of samples } & \multicolumn{1}{c|}{$\begin{array}{c}\text { Dimensions } \\
(\mathbf{m m})\end{array}$} \\
\hline 1. & $\begin{array}{l}\text { - } \begin{array}{l}\text { Cement }=7 \% \\
\text { Paper waste replacement of cement by } \\
\text { weight of cement weight } 2,4,6,8,10 \%\end{array} \\
\text { 2. }\end{array}$ & $\begin{array}{l}\text { For each percent of paper } \\
\text { waste three samples are } \\
\text { made, thus total samples } \\
=15\end{array}$ & $\begin{array}{c}150 \text { diameter } \\
300 \text { height }[10]\end{array}$ \\
\hline 3. & $\begin{array}{l}\text { Paper waste replacement of cement by } \\
\text { weight of cement } 2,4,6,8,10 \% \text { for Water } \\
\text { absorption test }\end{array}$ & $\begin{array}{l}\text { For each percent of paper } \\
\text { waste three samples are } \\
\text { made, thus total samples } \\
=15\end{array}$ & $\begin{array}{c}240 \times 240 \times 140 \\
{[10]}\end{array}$ \\
\hline $\begin{array}{l}\text { Cement }=7 \% \\
\text { Paper waste replacement of cement by } \\
\text { weight of cement } 2,4,6,8,10 \% \text { for } \\
\text { Accelerated erosion test }\end{array}$ & $\begin{array}{l}\text { For each percent of paper } \\
\text { waste three samples are } \\
\text { made, thus total samples } \\
=15\end{array}$ & $\begin{array}{c}240 \times 240 \times 140 \\
{[10]}\end{array}$ \\
\hline
\end{tabular}

\section{RESULTS}

\subsection{Compressive strength}

The samples were cured using hessian cloth wrapping while the compressive strength test was performed using Universal Testing Machine (UTM). The compressive strength test result is shown in Figure 7. As we can see from the Figure, with the addition of admixture paper waste, the strength starts to lower firstly, but after adding $8 \%$ paper waste by weight of cement, the compressive strength started to rise.

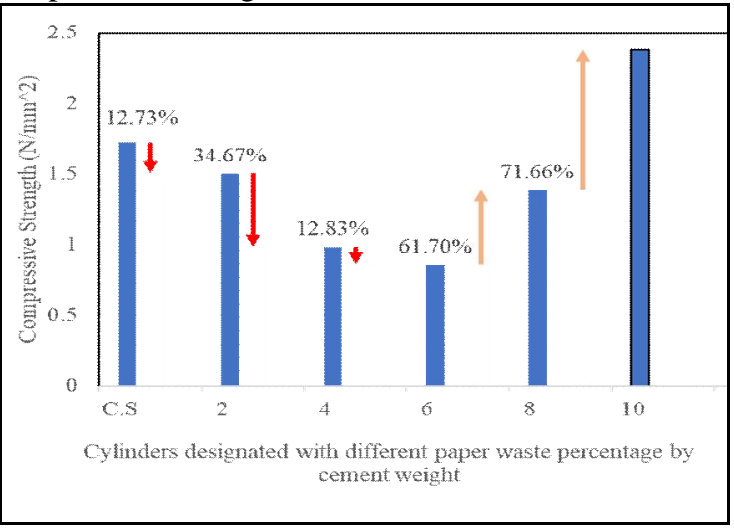

Figure 7: Comparision between control sample strength and different percentage of paper waste

\subsection{Shrinkage test}

In 2016, Kariawasam visited 25 buildings where cracks primary reason was shrinkage; therefore, his team conducted a shrinkage test on the wall samples. In this research, six walls are made to check shrinkage with $10 \%$ of paper waste and three control samples. The results are shown in Figure 8.

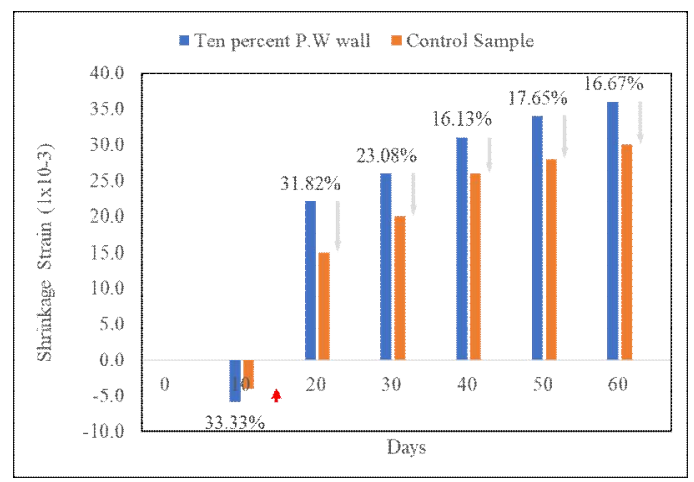




\subsection{Water absorption test}

For finding the water absorbability of paper waste stabilized rammed earth against rammed earth samples. The rammed earth samples were prepared and set up according to the standard [10]. The dimension of the samples was $240 \mathrm{~mm} \mathrm{x}$ $240 \mathrm{~mm} \times 140 \mathrm{~mm}$. Water absorption is shown in Table 2.

Table 2: Water absorption test results

\begin{tabular}{|c|c|c|}
\hline $\begin{array}{c}\text { Samples with the } \\
\text { paper waste } \\
\text { percentage by } \\
\text { cement weight }\end{array}$ & $\begin{array}{c}\text { Water absorption } \\
(\%)\end{array}$ & $\begin{array}{c}\text { COV } \\
(\%)\end{array}$ \\
\hline 0 & 6.5 & 1.3 \\
\hline 2 & 8.2 & 1.1 \\
\hline 4 & 9.2 & 0.3 \\
\hline 6 & 10.5 & 0.4 \\
\hline 8 & 12.3 & 2.2 \\
\hline 10 & 13.4 & 0.3 \\
\hline
\end{tabular}

\subsection{Accelerated erosion test}

To simulate heavy rainfall and find the erosion in rammed earth paper waste stabilized samples accelerated erosion test was conducted. Water was sprayed for one hour or until the sample is completed for the reason of finding erosion. The setup was made according to the standard [11]. The result is shown in Table 3.

Table 3: Erosion rate test result

\begin{tabular}{|c|c|c|}
\hline $\begin{array}{c}\text { Sample designation } \\
\text { by paper waste } \\
\text { percentage by } \\
\text { cement weight }\end{array}$ & $\begin{array}{c}\text { Erosion rate mm per } \\
\text { hour }\end{array}$ & $\begin{array}{c}\text { COV } \\
(\%)\end{array}$ \\
\hline 0 & 2.1 & 2.3 \\
\hline 2 & 2.2 & 3.9 \\
\hline 4 & 3.3 & 1.7 \\
\hline 6 & 3.53 & 3.4 \\
\hline 8 & 3.87 & 2.2 \\
\hline 10 & 4.23 & 4.8 \\
\hline
\end{tabular}

\section{CONCLUSIONS AND RECOMMENDATIONS}

This research aimed to reduce the cement percent content for the apparent reason of reducing the global greenhouse gas emission. Paper waste was used as an option to replace cement content. It can withstand load because of its chemical and physical composition. It reflected in the results. Hypothesis testing was made on all the results and, in some cases, left tail $\mathrm{t}$ distribution, and in some cases, right tail $\mathrm{t}$ distribution was conducted. Because we wanted to know that the drop and the rise in compressive strength of paper waste stabilized rammed earth sample has sufficient probability as the experimental data depicts. The result was satisfying, and hence we can look to the critical points concluded in this research are as follows:

- The higher percentage of paper waste in rammed earth construction showed better results than the lower percent rammed earth paper waste stabilizer.

- Although the shrinkage strain was increased a little bit with the addition of paper waste, it is not significant, and this problem already existed in sandy soil. Therefore, future work could be done to rectify the strain problem which exists in rammed earth construction.

- Water absorption and accelerated erosion test showed that paper waste had increased water absorbability and erosion. The water absorbability increased due to the presence of cellulose content in paper waste. But with $10 \%$ of paper waste addition, the higher end of paper waste percentage addition, water absorption is still well below the standard limit [11].

- Industries may utilize rammed earth construction with 8-10\% paper waste in sandy silt with gravel (SM) soil, especially in $10 \%$ paper waste whose strength is more than ordinary.

- Before using the 8 and $10 \%$ paper waste in rammed earth construction, the soil should be verified as per standard, and other required tests should be performed on the samples.

- Even though recent development and focus on sustainable constructions, there is a lack of building codes and doubts in rammed earth construction [6]. Therefore, more studies are required and recommended.

- Future research can be applied for gravelly type soil (GM or GS) as this research was carried out using sandy silt soil with gravel (SM)

- As the percentage of paper waste increased, it was noted that the strength was highest in 10 percentage paper waste addition. Therefore, future research work can be done utilizing paper waste with more percentage of paper waste

- The paper waste used in this research weight was $75 \mathrm{gsm}$, and cellulose content is $70 \%$; therefore, further research can be recommended lower and higher end of cellulose content 
Nouman Khan Usama et al., International Journal of Emerging Trends in Engineering Research, 9(7), July 2021, 865 - 869

\section{REFERENCES}

[1] G. Jain, V. Guptha, M. Pandey, Case Study of Construction Pollution Impact on Environment, IJETER., 2016.

[2] A. Gramlich, A Concise History of the Use of the Rammed Earth Building Technique Including Information on Methods of Preservation, Repair, and Maintenance, Historic Preservation, 2013.

[3] B. M. K. Bahar R, S, Performance of compacted cement stabilized soil. Cement vol. 26, pp. 811-820, 2004.

[4] M. A. O. M. W. P. Morel JC, building houses with local material, Building and Environment, vol. 36, pp. 1119 $-1126,2001$.

[5] W. Donkee, Advantages and disadvantages of earth rammed housing, 29 April 2020. [Online]. Available: https://www.wonkeedonkeetools.co.uk/earth-rammers/advan tages-and-disadvantages-of-earth-rammed-houses

[6] V. Maniatidis and P. Walker, Structural capacity of rammed earth in compression, J. Mater. Civ. Eng., vol. 20, no. $3, \quad$ pp. 230-238, 2008, doi: 10.1061/(ASCE)0899-1561(2008)20:3(230).

[7] E. Araldi, E. Vincens, A. Fabbri, Identification of the mechanical behaviour of rammed earth including water content influence. Mater Struct., vol. 51, pp. 88, 2018, doi: .org/10.1617/s11527-018-1203-2

[8] N. Cristelo, S. Glendinning, T. Miranda, D. Oliveira, and R. Silva, Soil stabilization using alkaline activation of fly ash for self compacting rammed earth construction, Constr. Build. Mater., vol. 36, pp. 727-735, 2012, doi: 10.1016/j.conbuildmat.2012.06.037

[9] V. Shah, S. Khorasiya, A. Patel and A. Parmar, Rice husk ash as a stabilizer in rammed earth, International Journal for Scientific Research \& Development, vol. 1, no. 1, pp. 15-16, 2013

[10] B. Khadka and M. Shakya, Comparative compressive strength of stabilized and un-stabilized rammed earth, Mater. Struct. Constr., vol. 49, no. 9, pp. 3945-3955, 2016, doi: 10.1617/s11527-015-0765-5

[11] N. Standard, Materials and workmanship for earth building, Standards Newzeland, vol. 1, no. Incorporting amendent, p. 89, 1998.

[12] R. Vroomen, Gypsum stabilized earth, Eindhoven University of Technology, 2007
[13] B. Windstorm and A. Schmidt, A Report of Contemporary Rammed Earth Construction and Research in North America, Sustain., vol. 5, no. 2, pp. 400-416, 2013, doi: 10.3390/su5020400.

[14] V. Hospodarova, N. Stevulova, and A. Sicakova, Possibilities of using cellulose fibres in building materials, IOP Conf. Ser. Mater. Sci. Eng., vol. 96, no. 1, 2015, doi: 10.1088/1757-899X/96/1/012025.

[15] R. lew, Bio energy consult, 6 feb 2020. [Online]. Available:

https://www.bioenergyconsult.com/solid-waste-management -in-pakistan/.

[16] N. Ferronato and V. Torretta, Waste mismanagement in developing countries: A review of global issues," Int. J. Environ. Res. Public Health, vol. 16, no. 6, 2019, doi: 10.3390/ijerph16061060.

[17] F. R. Arooz and R. U. Halwatura, Mud-concrete block (MCB): mix design \& durability characteristics, Case Stud. Constr. Mater., vol. 8, no. November 2017, pp. 39-50, 2018.

[18] Q. B. Bui, J. C. Morel, S. Hans, and P. Walker, Effect of moisture content on the mechanical characteristics of rammed earth, Constr. Build. Mater., vol. 54, pp. 163-169, 2014,doi:10.1016/j.conbuildmat.2013.12.067.10.1016/j.csc m.2017.12.004.

[19] N. Ferronato and V. Torretta, Waste mismanagement in developing countries: A review of global issues, Int. $J$. Environ. Res. Public Health, vol. 16, no. 6, 2019, doi: 10.3390/ijerph16061060.

[20] C. Beckett, Effect of compaction water content on the strength of cement-stabilized rammed earth materials, Canadian geotechnical journal, vol. 51, no. NRC Research Press, pp. 583--590, 2014.

[21] R. Vignesh, Experimental study on partial replacement of cement by sugarcane bagasse ash (SCBA," ISSN, pp. 2455-4200, 2017.

[22] D. Ciancio, Advances on the assessment of soil suitability for rammed earth, Construction and Building Materials, no. Elsevier, pp. 40--47, 2013.

[23] K.Kariyawasam, Construction and Building Materials, Construction and Building Materials $r$, vol. 105, no. Elsevier, pp. 519--527, 2016. 